\title{
Organic inputs and farmers' management strategies in millet fields of western Niger
}

\author{
Eva Schlecht ${ }^{\mathrm{a}, *}$, Andreas Buerkert ${ }^{\mathrm{b}}$ \\ ${ }^{a}$ Institute for Animal Production in the Tropics and Subtropics, University of Hohenheim, D-70593 Stuttgart, Germany \\ ${ }^{\mathrm{b}}$ Department of Ecological Crop Production and Agroecosystems Research in the Tropics and Subtropics, Institute of Crop Science, \\ University of Kassel, D-37213 Witzenhausen, Germany
}

Received 11 June 2003; received in revised form 7 October 2003; accepted 28 November 2003

Available online 17 January 2004

\begin{abstract}
Research on soil fertility management in sub-Saharan Africa was criticized lately for largely ignoring farmers' management strategies and the underlying principles. To fill this gap of knowledge, detailed interviews were conducted with 108 farm households about their rationale in managing the soil fertility of 307 individual fields in the agro-pastoral village territory of Chikal in western Niger. To amplify the farmers' information on manuring and corralling practices, repeated measurements of applied amounts of manure were carried out within six $1-\mathrm{km}^{2}$ monitoring areas from February to October 1998.

The interviews revealed that only $2 \%$ of the fields were completely fallowed for a period of $1-15$ years, but $40 \%$ of the fields were at least partially fallowed. Mulching of crop residues was mainly practiced to fight wind erosion but was restricted to $36 \%$ of the surveyed fields given the alternative use of straw as livestock feed. Manure application and livestock corralling, as most effective tools to enhance soil fertility, were targeted to less than $30 \%$ of the surveyed fields. The application of complete fallow and manuring and corralling practices were strongly related to the households' endowment with resources, especially with land and livestock. Within particular fields, measures were mainly applied to spots of poor soil fertility, while the restoration of the productivity of hard pans was of secondary importance. Given the limited spatial coverage of indigenous soil fertility measures and their strong dependence on farmers' wealth, supplementary strategies to restrict the decline of soil fertility in the drought prone areas of Niger with their heavily weathered soils are needed.
\end{abstract}

(c) 2004 Elsevier B.V. All rights reserved.

Keywords: Farmers' knowledge; Traditional soil fertility management; Manure decay; Sahel

\section{Introduction}

A declining per capita supply with staple crops in sub-Saharan Africa over the past 10-15 years (FAO, 2002) and the need for better crop-livestock integra-

* Corresponding author. Tel.: +49-711-459-3640; fax: +49-711459-3702.

E-mail address: eset@uni-hohenheim.de (E. Schlecht). tion (McIntire et al., 1992) have given rise to numerous studies on conservation and improvement of soil fertility in this region. The majority of these studies focused on technical aspects of the application of various amounts of crop residues and livestock manure without or in combination with mineral fertilizers, and on their impact on soil characteristics and crop yields (Bationo et al., 1993; Brouwer and Powell, 1998; Ikpe et al., 1999; Buerkert et al., 2000). Another 
important research topic was the assessment of nutrient budgets at the plot, farm, community and regional level (Stoorvogel et al., 1993; Buerkert and Hiernaux, 1998; Hiernaux et al., 1998; Van den Bosch et al., 1998). Both approaches have been criticized recently for overlooking farmers' management strategies and the socioeconomic rationales behind these (Scoones and Toulmin, 1998). However, several studies analyzing farmers' soil fertility management have also been published. Buerkert et al. (1996) documented the judicious use of residual fertility around farmers' moving hamlets to increase the productivity of acid sandy soils in western Niger. Harris and Yusuf (2001) presented a detailed analysis of cropland and manure management of three farm households in the Kano close settled zone of northern Nigeria. Institutional arrangements of crop residue and manure exchange between households and manuring practices were studied by Hoffmann et al. (2001) in the close settled zone of Dundaye as well as in the Zamfara forest reserve of northern Nigeria. Farmers' perception of wind erosion (Sterk and Haigis, 1998) of changes in fallow practices and general cropland management strategies (Wezel and Haigis, 2002) as well as farmers' classification of soil types and measures applied to particular fields (Osbahr and Allan, 2003) were investigated in western Niger. However, none of these studies investigated how and why farmers managed fields the way they did.

In examining specific soil fertility measures applied to individual fields, the present study tried to unravel case-dependent reasons behind the timing and spatial distribution of specific measures. Particular emphasis was placed on determining if, why and when the measures were targeted to particular areas within fields. To corroborate and amplify the farmers' information on the application of livestock dung through manuring and corralling practices, quantitative measurements of manure deposit and decay were carried out under on-farm conditions in representative areas within the village territory.

\section{The Chikal territory}

The study was conducted among farmers of Chikal Chaniassou and several smaller satellite villages and solitary homesteads within the village territory (298 $\mathrm{km}^{2}$ ) of Chikal (Schlecht et al., 2001a). Chikal $\left(14^{\circ} 25^{\prime} \mathrm{N}, 3^{\circ} 26^{\prime} \mathrm{E}, 249 \mathrm{~m}\right)$ is situated $185 \mathrm{~km} \mathrm{NE}$ of Niger's capital Niamey, at the border of the semiarid Southern Sahelian zone with the arid Northern Sahelian zone. There the rainy season typically lasts from June to September and peaks in July and August. From 1990 to 1998 , an average of $361 \mathrm{~mm}_{\text {year }}{ }^{-1}$ $( \pm 110.6)$ of rain fell in 35 days $( \pm 10.5)$ (Chikal Meteorological Station). The mean annual temperature is $29{ }^{\circ} \mathrm{C}$, with monthly averages of $33{ }^{\circ} \mathrm{C}$ in April, the hottest month, and $24{ }^{\circ} \mathrm{C}$ in January, the coolest month.

Geologically, the study area is located at the edge of the 'Continental Terminal' sandstone plateau and the fossil river valley of the 'Dallol Bosso'. The eastern part of the study area, dominated by plateaus with shallow stony and iron-rich soils, is not suited for cropping. The northeastern part of the territory is dominated by a fixed quaternary dune covering 2000 ha, while the western part- 15,500 ha - lies in the fossil river valley. On the border between the plateaus and the Dallol, a band of depressions and weakly inclined plains extends in north/south direction. Inclined plains also occur at the border of the plateaus with the Dune. On these Pediments, which occupy 6500 ha, strongly stratified Arenosols are found on sandy micro-dunes, whereas strongly stratified and eroded Cambisols occur on loamy substrates. The Dallol and the Dune are dominated by Arenosols; in the rainy season of 1997, they were cropped on $75 \%$ and $45 \%$ of their surface, whereas on the Pediments $18 \%$ of the surface was cropped. In small-scale depressions, which occur in the Dallol, on the Dune and on the Pediments, crops were grown on $2 \%$ of the total area of 2700 ha (Schlecht et al., 2001a).

\section{Methods}

\subsection{Soil fertility management survey}

From January to May 1998, a soil fertility management survey was conducted in 108 randomly selected households from 15 villages and hamlets across the territory. Through detailed, structured interviews, qualitative and quantitative information was collected about household characteristics and soil 
fertility management practices applied to individual fields of each of these households. The first part of the soil fertility interview referred to general information on the field such as its location within the territory, distance from the homestead and the crops grown in the 1997 rainy season. Additional points of interest were the area under fallow, the duration of fallow on a field during the past 15 years and the comparison of the part of the field fallowed in the 1996/1997 dry season to the part fallowed 3 years previously during the 1993/1994 dry season.

Specific questions were asked about each measure, which farmers claimed to apply in the 1997/1998 dry season. If a farmer stated to burn crop residues on a field, he was asked to specify their type, origin and quantity. A detailed description of the burning procedure and of the criteria that led to its application was followed by an evaluation of the benefits and the frequency of burning on this field during the previous 10 years. For the application of organic materials, that is mulch of plant origin, or dung from corralling animals on the field or from the application of dry farmyard manure (FYM), the following issues and their causes were explored: origin and composition of the organic material, amounts applied, homogeneous or heterogeneous distribution on the field, selection criteria for target spots, criteria determining the start and duration of the application period, proportion of field surface covered by organic material at the end of the application period, losses of material from the end of the application period until the start of the cropping season, frequency of application of organic material during the previous 10 years, specific benefits of the measures for the particular field, and the combination of the individual measures with other measures.

\subsection{Monitoring of corralling practices}

Within the territory, six monitoring sites were selected. To represent the three geomorphological units that were used for cropping, two sites were installed on the Dune, two in the Dallol and two on Pediments, whereby only one of the fields covered by the interviews was also located within a monitoring area. Around these sites, areas of $1 \mathrm{~km}^{2}$ were delineated. Within these areas, all locations with high amounts of faeces from corralling or manual application of FYM were identified and their size was measured with a differential global positioning system (GPS). Starting in February 1998, the faecal mass deposited on each of the detected spots was determined by collecting dung within twelve $1 \mathrm{~m}^{2}$ sampling areas distributed evenly within four equally large quarters of the polygon spots (more or less round shaped). All faeces deposited or remaining on the soil surface plus at maximum $1 \mathrm{~cm}$ below soil surface were collected and were separated by visual inspection into manure from cattle, small ruminants (sheep and goats) and other species (camels, donkeys). After weighing on a mobile scale $( \pm 2 \mathrm{~g}$ precision), the dung was redistributed within the sampling area. From the 12 sampling areas, 1 pooled sub-sample of about $50 \mathrm{~g}$ was kept for each type of faeces to determine the average dry matter (DM) and organic matter (OM) content of the dung. The spots were revisited and sampled again every 5 weeks until July and again 10 weeks later, at the end of the rainy season (October). At each visit, the size of those spots that had been newly installed was measured and the spots were then sampled for manure in the same way as the older spots.

\subsection{Data analysis}

Data analysis was performed with SAS 8.1 (2000). The qualitative answers given in the interviews were transformed into dummy or categorical variables wherever appropriate. Since the number of farmers responding to questions concerning a particular management strategy varied even within the series of questions concerning this measure, the number of answers obtained for a particular question did not necessarily add up to the total number of fields concerned or the number of farmers applying the measure. For this reason, the absolute numbers rather than percentages are given.

The quantitative information given by farmers was subjected to factorial analysis of variance using the general linear model procedure and to linear regression. Correlations between different qualitative variables were analyzed through contingency tables using the Frequency procedure. To examine correlations between variables, chi-square tests were computed and the evaluation of the strength of an association was based on Spearman's correlation coefficient. In case of correlation $(r>0.5)$, nonparametric data was 
further analyzed using the Kruskal-Wallis test. Probabilities and correlation coefficients obtained through nonparametric procedures were identified by $p$ and $r$, and probabilities and correlation coefficients determined through linear models by $P$ and $R$.

Logistic regression analysis was performed on the digital YES/NO information whether or not a field was fallowed, mulched, corralled or manually manured to investigate the relationship between the discrete responses and the explanatory variables. The latter were the total number of plots (PLOTS) managed by the household, labour availability for soil fertility management (WORK), number of cattle $\left(\mathrm{TLU}_{\mathrm{c}}\right)$ and small ruminants $\left(\mathrm{TLU}_{\mathrm{sr}}\right)$ managed $^{1}$ and distance of the field from the homestead (DIST):

$$
\begin{aligned}
\text { MEASURE }= & \beta_{0}+\beta_{1} \text { PLOTS }+\beta_{2} \text { WORK } \\
& +\beta_{3} \text { TLU }_{\mathrm{c}}+\beta_{4} \text { TLU }_{\mathrm{sr}}+\beta_{5} \mathrm{DIST}+\varepsilon
\end{aligned}
$$

The model was run separately for each measure, whereby only one field per household $(n=108)$ was considered in each run, since the first four of the above mentioned variables were identical for different fields of one household. If two, three or four fields per household were affected by the measure, selection among fields of each category was based on randomization.

Two types of statistical analyses were computed on the amounts of manure from monitored corralled spots. First, it was analyzed whether the amount of manure determined at each sampling date (log-transformed values of DM) was influenced by site geomorphology, whereby the actual (ith sampling) proportion of cattle manure in the dung mixture was considered as a co-variable. The preceding principal component analysis of the data revealed that the site itself, the initial amount of small ruminant manure in the dung mixture and the age of the corral at first sampling did not affect the amount of manure. Therefore, these parameters were not considered in the model. Subsequently, an exponential decay model was fitted to the (residual) amount of manure DM determined at each dry-season sampling date (samplings 1-5) for 25 corralled sites from which data for all sampling dates were available. Finally, monthly

\footnotetext{
1 TLU Tropical livestock unit, equivalent to $250 \mathrm{~kg}$ live weight.
}

disappearance rates of manure DM were calculated for the 25 corrals and subjected to a time series analysis.

\section{Results}

\subsection{Characterization and general management of fields}

The basic characteristics of the 108 households covered by the soil fertility management survey are summarized in Table 1. Since at regular intervals fields are turned into fallows and vice versa, no differentiation was made between the size of fallow and crop land, the overall average size of a plot being 9.5 ha $( \pm 7.2)$.

Information on field history and specific soil fertility measures was obtained for 307 fields, which were owned by the household head in $98 \%$ of all cases. For 96 households, the interviews covered all fields, but accidentally 1, 2 and 3 fields per household were not considered in seven, four and one cases, respectively.

Of the 307 survey fields, 154 were located in the Dallol, 101 on pediment sites, 34 on the Dune and 18 in small-scale depressions located within the three major geomorphologic units. Fields in the Dallol were closer to the homesteads than fields located on the other geomorphologic formations $(P<0.001)$, the average distance being $3.5 \mathrm{~km}( \pm 4.51)$. Dune fields, fields on pediments and fields in depressions, respectively, were on average $8.4( \pm 7.06), 10.1( \pm 8.88)$

Table 1

Characteristics of the 108 households who participated in the soil fertility management survey in Chikal/Niger

\begin{tabular}{lcc}
\hline Parameter & Mean & S.D. \\
\hline Age of household head (years) & 53 & 12.3 \\
Total family members $(n)$ & 12 & 7.4 \\
Migratory members $(n)$ & 2 & 2.4 \\
Soil fertility workers $(n)^{\mathrm{a}}$ & 2.8 & 1.74 \\
Fallow plots $(n)$ & 0.6 & 0.78 \\
Cultivated plots $(n)$ & 2.2 & 1.07 \\
Cattle (TLU) & 2.3 & 3.47 \\
Small ruminants (TLU) & 1.4 & 1.55 \\
Total livestock (TLU) & 5.5 & 6.05
\end{tabular}

${ }^{\mathrm{a}}$ The calculation considered only permanently present males $>15$ years. Due to reduced contribution to field work, men $>55$ years were weighted with a factor of 0.2 . 
and $9.1 \mathrm{~km}( \pm 12.98)$ away from the homestead. This correlation between the geomorphologic unit and the distance to the homestead is due to the concentration of settlements in the Dallol as illustrated by Schlecht et al. (2001a).

During the 15 years preceding the interview (that is since 1983), out of the 307 fields 118 had not been fallowed, whereas 66 fields had been fallowed for a period of 1-15 and even more years (Fig. 1a). Of the latter fields, 52 had also been fallowed in the rainy season of 1997. On 123 fields, an estimated 44\% $( \pm 19.5)$ of the surface was reportedly fallowed for a certain number of years, whereas the rest of the field was cultivated. For 50 fields where the duration of the partial fallow was specified, $42 \%$ were partially fallowed for $1-3$ years, $44 \%$ for $4-10$ years and $14 \%$ for 10-30 years. For 38 fields, the position of the fallowed area itself changed during the fallowing period, for the remaining 85 fields the position of the fallowed area remained unchanged during the entire fallowing period. Between 1993/1994 and $1996 / 1997$, there were minor changes in the proportion of field surface fallowed in subsequent years, and only 21 fields cultivated in 1993/1994 had been turned into fallow for two thirds or more of their surface by 1996/1997 (Table 2). Among the five explanatory variables considered in the logistic regression analysis, especially the total number of plots but also the number (TLU) of cattle managed by a household affected the decision about whether or not a field was totally fallowed for at least 1 year. An increase in any of the two variables enhanced the
Table 2

Fallowing practiced in 307 fields during the dry season of 1996/ 1997 as compared to $1993 / 1994$

\begin{tabular}{lrrrc}
\hline Part of field fallowed & \multicolumn{4}{l}{ Part of field fallowed in 1993/1994 } \\
\cline { 2 - 5 } in 1996/1997 & 0 & $<33 \%$ & $33-67 \%$ & $68-100 \%$ \\
\hline 0 & 110 & 3 & 2 & 5 \\
$<33 \%$ & 16 & 27 & 4 & 3 \\
$33-67 \%$ & 17 & 4 & 37 & 7 \\
$68-100 \%$ & 21 & 2 & 1 & 48 \\
\hline
\end{tabular}

Data are from Chikal/Niger.

farmers' readiness to put their field to a complete fallow. The application of a partial fallow was only related to the distance of the field to the homestead, and the probability for the application of this measure increased with increasing distance.

Most of the fields cultivated in the 1997 rainy season were sown to pearl millet (Pennisetum glaucum (L.) R. Br.), the main staple crop in the region. Cowpea (Vigna unguiculata (L.) Walpers.) and sorghum (Sorghum bicolor (L.) Moench) were commonly intercropped with millet (Fig. 1b). Intercropping densities for millet at Chikal average 33\%, but a high variation between individual fields and between years is observed (Muehlig-Versen, 2001). Of secondary importance was sorrel (Hibiscus sabdariffa L.), interplanted on about $40 \%$ of the fields, whereas groundnut (Arachis hypogaea L.) and bambara groundnut (Vigna subterranea (L.) Verd.) were only occasionally grown. Except for pure stands of sorghum, which were primarily reported for fields on Pediments and in depressions, the proportion of fields cultivated with a)

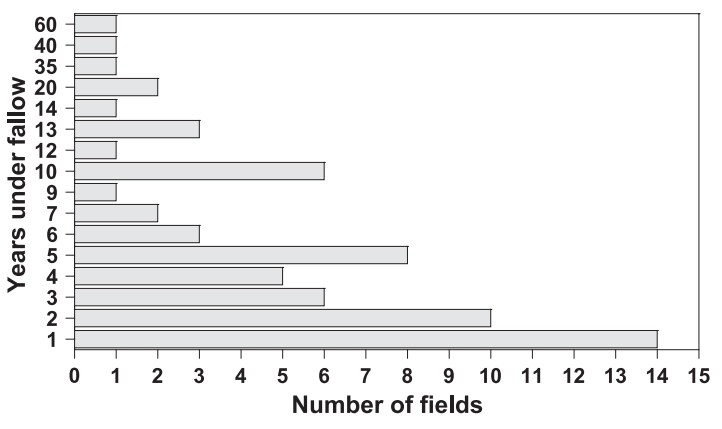

b)

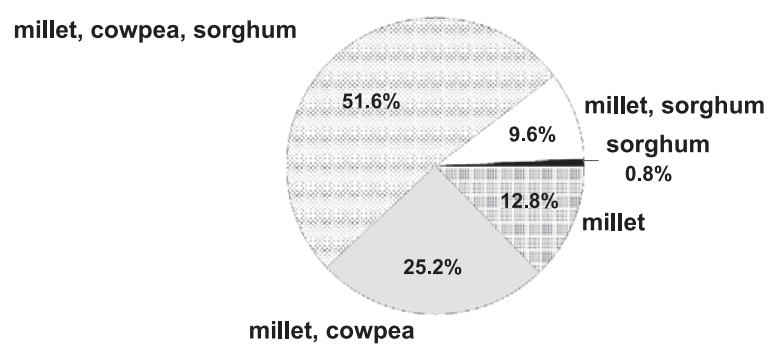

Fig. 1. Fallow duration on fields $(n=66)$ completely fallowed within the period of $1983-1998$ (a) and proportion of fields $(n=245)$ cultivated with different associations of crops in the rainy season of 1997 (b) in the territory of Chikal/Niger. 
the various crop associations were similar for the different geomorphologic units.

\subsection{Crop residue management: burning and mulch- ing practices}

For 11 out of 307 fields, each managed by a different household, the farmers confirmed that they regularly burned crop residues. While eight farmers claimed to burn them every year, one farmer carried out this measure only every third year. The remaining two farmers only used fire if a high amount of millet stalks remained on the field at the end of the dry season. On 3 fields, branches of shrubs growing in the field, which were cut at field preparation (FebruaryApril), were also burned and, on another 2 fields, household waste was burned along with the crop residues. In all cases, the material was gathered on heaps, which were allowed to dry for a few days before burning. The heaps were installed on selected spots within a field, either on hardpans or on sandy spots, but sometimes also on spots of high soil fertility where considerable amounts of residues from the previous rainy season had accumulated. Farmers did not clearly quantify the amounts of organic material burned. The answers ranged from 7 to 50 bundles of millet stalks with approximately $8.2 \mathrm{~kg}$ dry matter per bundle to $10-20 \%$ of the crop residue yield at grain harvest. These figures translate to a range of 100-650 kg DM ha ${ }^{-1}$.

Burning is mostly done a few weeks before the rainy season starts that is after late April. The farmers' major concern was to avoid bush fires; therefore, they delayed burning until the beginning of the monsoon, when the main wind direction has changed from East to South-West and there is a constant but moderate current of humid air. Two other important aspects for the late timing of burning were the reduction of the millet stem borer (Dysdercus voelkeri Schmidt) and the preservation of soil humidity through prolonged soil cover by millet stalks, which contributes to the mulch effect. The major benefits farmers expect from burning were an easier field preparation and seeding in the subsequent rainy season $(n=10)$. Farmers also noticed that burning increased soil fertility $(n=5)$ and millet production $(n=3)$. According to the farmers, the beneficial effects of burning organic material lasted for one $(n=7)$ or two $(n=3)$ rainy seasons.
Seventy-two farmers managing 111 of the 307 fields, affirmed to purposefully apply mulch materials. Out of these 111 fields, 103 were mulched every year, 7 were mulched once in 2 years and 1 field was mulched once in 4 years only. On 101 of the fields, the mulch material consisted of millet stalks plus the branches of shrubs growing in the field, which were applied after clearing. On 9 fields, only millet stalks and on 1 field only branches of shrubs were used as mulch. Most of the mulch material was gathered on the field itself, only in one case also on neighboring fallow plots.

Forty-one out of 72 farmers, who responded to the question, declared unanimously that they started their mulching activities at the onset of erosive winds in late October. On the majority of fields $(n=99)$, the mulch was concentrated on particular spots, preferentially spots of poor soil fertility $(n=64)$ or hardpans $(n=32)$. Spots where water stagnated during the rainy season were selected for mulching on 3 fields only. In the context of the present study, spots of poor soil fertility are sandy spots that are at most covered by a thin structural erosion crust at the initial stage (Casenave and Valentin, 1989), while hardpans are characterised by a compacted soil crust. Farmers estimated that mulching material covered on average $68 \%$ ( $\pm 16.1, n=111)$ of the field surface.

For 80 fields losses of mulching material from its application until the start of the cropping season were reported, whereas for 31 fields no losses were reported. The average proportion of material lost was estimated at $43 \%( \pm 23.3, n=74)$. The estimated extent of losses was not related to the season of mulch application, nor to the proportion of the field surface covered with mulch. However, average losses were perceived to be higher on hardpans and on spots of stagnating water ( $46 \%$ and $48 \%$, respectively) than on sandy spots of poor soil fertility $(17 \% ; P<0.001)$. Losses of mulching material were mainly attributed to termite activity $(n=55)$, livestock trampling and consumption $(n=10)$ or the joint influences of termites and livestock or men, respectively $(n=12)$.

While the principal motive given for the start of applying crop residue mulch was the reduction of soil erosion (see above), enhanced soil fertility for millet production $(n=105)$, facilitated cropping $(n=2)$ and reduced wind erosion $(n=1)$ were described as benefits of mulching. Among the five parameters consid- 
ered in the logistic regression, only the distance of the field to the homestead had a significant influence on the application of mulch, whereby the probability for mulching decreased with increasing distance.

\subsection{Application of dry farmyard manure}

On 48 out of the 307 fields, farmers $(n=48)$ applied FYM in the 1997/1998 dry season (Table 3). On 22 fields less than $100 \mathrm{~kg} \mathrm{FYM} \mathrm{ha}{ }^{-1}$ were applied, amounts of 200-500 $\mathrm{kg} \mathrm{FYM} \mathrm{ha}{ }^{-1}$ were claimed to be used on 8 fields and, for 1 field, the farmer estimated that he had placed $850 \mathrm{~kg}$ FYM $\mathrm{ha}^{-1}$. On 21 of the 48 fields, household waste was applied in addition to FYM. However, the application of this material seemed to be very sporadic. Only three farmers were able to estimate the amount of household wastes applied at 3 (two farmers) and $16 \mathrm{~kg}$ $\mathrm{ha}^{-1}$ (one farmer) per year. On another 9 out of the 48 fields, FYM application was purposefully combined with the application of millet stalks, and two farmers specified that this combination was needed because the amounts of FYM applied were not sufficient to maintain or improve soil fertility.

From the replies of 30 out of 48 farmers, it appeared that FYM was mainly applied in weekly intervals $(n=28)$, sometimes also biweekly $(n=2)$ or monthly $(n=2)$, but the amount of FYM applied per hectare was not correlated to the frequency of manure application.
The farmers $(n=42)$ who commented on the composition of farmyard manure used mostly a mix of faeces from cattle and small ruminants $(n=22)$, which could also contain some faeces from donkeys and camels. Manure from small ruminants was used in 12 cases, manure from donkeys and camels in 6 cases and pure cattle manure in 2 cases. On 13 fields FYM application started directly after millet harvest (October), for the remaining 35 fields in the early dry season (November/December). Starting FYM application in the Harmattan season (November onwards) was seen as a means to assure cover of the manure with sand and thus avoid manure losses. Some farmers even considered this sand-trapping quality of FYM as equally important as its fertilizing effect.

On 31 fields the manure was concentrated on particular spots, for the other 17 fields farmers claimed to have spread FYM homogeneously. The reasons for applying different amounts of FYM on different spots were described as 'different manure needs' $(n=24)$ and 'different size of particular spots' $(n=10)$, whereby the spots receiving FYM were mainly spots of poor soil fertility $(n=25)$ and hardpans $(n=5)$. The correlation between the area covered by FYM and the size of the whole field amounted to $R=0.63(P<0.001, n=43)$. However, when the proportion of the field surface covered with manure increased, the amount of FYM applied to the whole field $\left(\mathrm{kg} \mathrm{DM} \mathrm{ha}{ }^{-1}\right)$ slightly decreased $(R=-0.33$, $P=0.04, n=38)$.

Table 3

Characteristics of manually manured and corralled fields as given by interviewed farmers of Chikal/Niger in the 1997/1998 dry season

\begin{tabular}{|c|c|c|c|c|c|c|c|c|}
\hline \multirow[t]{2}{*}{ Parameter } & \multicolumn{4}{|c|}{ Manually manured fields } & \multicolumn{4}{|c|}{ Corralled fields } \\
\hline & $n$ & Mean & S.D. & Median & $n$ & Mean & S.D. & Median \\
\hline Field size (ha) & 45 & 10.8 & 7.82 & 8.8 & 30 & 11.3 & 7.83 & 9.4 \\
\hline Size of individual corral $\left(\mathrm{m}^{2}\right)$ & & - & & & 37 & 118 & 105.9 & 95 \\
\hline Livestock corralled (TLU) & & - & & & 28 & 27 & 25.8 & 19 \\
\hline Duration of corralling (days field ${ }^{-1}$ ) & & - & & & 36 & 76 & 93.4 & 29 \\
\hline Number of corral shifts $(n)$ & & - & & & 36 & 4.7 & 5.14 & 3.0 \\
\hline Manure applied $^{\mathrm{a}}\left(\mathrm{kg} \mathrm{DM} \mathrm{ha}{ }^{-1}\right)$ & 39 & 145 & 172.4 & 82 & 27 & 3703 & 7723.6 & 1474 \\
\hline Area covered ( $\%$ of field surface $)$ & 47 & 23 & 21.8 & 20 & 39 & 22 & 23.4 & 10 \\
\hline Manure losses (\% of applied DM) & 22 & 26 & 29.9 & 15 & 38 & 29 & 33.9 & 30 \\
\hline Application frequency in 10 years $(n)$ & 46 & 9 & 2.9 & 10 & 38 & 7 & 3.4 & 9 \\
\hline
\end{tabular}

The total number of fields covered by the survey was 48 manually manured and 40 corralled fields; figures $(n)$ in the table indicate the number of fields the respective information was obtained for.

${ }^{a}$ For corralled fields estimated as follows: manure $\mathrm{DM}=$ duration of corralling*TLU*nocturnal faecal excretion (Schlecht et al., 1998); corral size $=19.7 \mathrm{~m}^{2} /$ adult animal $*$ animal numbers $*$ number of corral shifts. $19.7 \mathrm{~m}^{2}$ is the average space occupied by an adult animal within a corral (P. Hiernaux, pers. comm.). 
Manure losses during the dry season were attributed to termite activity $(n=19)$, recurrent passage of livestock $(n=2)$ or the combination of both factors $(n=1)$; no specification was given in 26 cases. The aim of the targeted manure application was to foster plant development and improve the fertility of infertile spots, and farmers $(n=46)$ unanimously defined the specific benefit of FYM application to the particular field as causing a 'good development of millet plants'.

\subsection{Corralling livestock on fields}

Forty fields managed by 40 different households were corralled in the dry season of 1997/1998 (Table 3 ), whereby corralling was purposefully combined with the application of crop residue mulch on 8 of these fields. Fourteen farmers confirmed that they specifically corralled the particular field to improve its fertility, but 24 farmers stated that the livestock manager had decided to corral the particular field, whereby nine of the latter farmers explicitly welcomed the herders' decision.
Twenty-two of the 40 fields were corralled by transhumant herds, to which only in one case the household's own animals were associated. In nine cases, members of the farmer's household managed the corralled livestock and, for the remaining 9 fields, a villager supplied the animals needed for corralling. Eighteen out of 38 farmers who answered the question stated that the household supplying the corralled animals was the same every year; in the other 20 cases, different livestock managers supplied corralling services in subsequent years. Only six farmers had established a formal corralling contract with the livestock manager, who in two cases was a transhumant herder; in three cases, a household member and in the remaining case a villager. But even without formal contracts, farmers $(n=33)$ paid the livestock manager for the corralling service. Fees were given to 19 out of 22 transhumant herders and 7 out of 9 villagers and household members each. Corralling services were mostly remunerated with bundles of millet cobs. From the information given by the farmers $(n=17)$, it was calculated that livestock managers

Table 4

Manure mass and composition determined on corralled spots installed within two $1 \mathrm{~km}^{2}$ sampling sites each at three different geomorphologic units in Chikal/Niger in the second half of the 1997/98 dry season and the rainy season of 1998

\begin{tabular}{|c|c|c|c|c|c|c|c|}
\hline \multirow{3}{*}{$\begin{array}{l}\text { Month in } 1998 \\
\text { (Sampling no) } \\
\text { Season }\end{array}$} & \multirow[t]{3}{*}{$\begin{array}{l}\text { Geomorph. } \\
\text { Unit }\end{array}$} & \multirow[t]{3}{*}{$\begin{array}{l}\text { Corrals } \\
\text { (n) }\end{array}$} & \multicolumn{3}{|c|}{$\begin{array}{l}\text { Manure mass on corralled spots } \\
\left(\mathrm{kg} \mathrm{ha}^{-1}\right)\end{array}$} & \multicolumn{2}{|c|}{$\begin{array}{l}\text { Manure composition* } \\
\left(\mathrm{DM}, \mathrm{g} \mathrm{kg}^{-1}\right)\end{array}$} \\
\hline & & & \multirow{2}{*}{$\begin{array}{l}\text { Dry matter } \\
\text { Mean }\end{array}$} & \multicolumn{2}{|l|}{$\begin{array}{l}\text { Organic } \\
\text { matter }\end{array}$} & \multirow{2}{*}{$\begin{array}{l}\text { Cattle } \\
\overline{\text { Mean }}\end{array}$} & \multirow{2}{*}{$\begin{array}{l}\begin{array}{l}\text { Small } \\
\text { ruminants }\end{array} \\
\text { Mean }\end{array}$} \\
\hline & & & & Mean & S.D. & & \\
\hline \multirow[t]{3}{*}{ February (1) Dry season } & Dallol & 17 & $1924.4^{\mathrm{a}}$ & 1110.4 & 558.63 & 573 & 211 \\
\hline & Dune & 14 & $3302.4^{\mathrm{b}}$ & 1905.5 & 882.15 & 878 & 46 \\
\hline & Pediments & 8 & $3569.6^{\mathrm{b}}$ & 2059.6 & 1593.48 & 788 & 166 \\
\hline \multirow[t]{3}{*}{ March (2) Dry season } & Dallol & 18 & $1429.9^{\mathrm{a}}$ & 825.1 & 734.74 & 595 & 201 \\
\hline & Dune & 14 & $2051.8^{\mathrm{ab}}$ & 1183.9 & 888.77 & 836 & 67 \\
\hline & Pediments & 9 & $2372.9^{\mathrm{b}}$ & 1369.2 & 885.59 & 746 & 180 \\
\hline \multirow[t]{3}{*}{ April (3) Dry season } & Dallol & 21 & 1605.4 & 926.3 & 914.31 & 579 & 259 \\
\hline & Dune & 14 & 2352.0 & 1357.1 & 912.94 & 857 & 82 \\
\hline & Pediments & 9 & 2450.3 & 1413.8 & 709.80 & 790 & 189 \\
\hline \multirow[t]{3}{*}{ June (4) Dry season, end } & Dallol & 21 & 1406.5 & 811.6 & 582.56 & 587 & 254 \\
\hline & Dune & 14 & 1927.8 & 1112.3 & 607.14 & 829 & 108 \\
\hline & Pediments & 9 & 1712.9 & 988.4 & 705.46 & 722 & 249 \\
\hline \multirow[t]{3}{*}{ July (5) Rainy season } & Dallol & 21 & 1530.6 & 883.1 & 898.42 & 604 & 214 \\
\hline & Dune & 14 & 2133.4 & 1231.0 & 963.54 & 854 & 87 \\
\hline & Pediments & 9 & 1622.4 & 936.1 & 545.46 & 778 & 185 \\
\hline \multirow[t]{3}{*}{ October (6) Rainy season, end } & Dallol & 21 & 564.4 & 325.7 & 301.27 & 606 & 224 \\
\hline & Dune & 13 & 1200.0 & 692.4 & 347.83 & 867 & 51 \\
\hline & Pediments & 7 & 914.7 & 527.8 & 318.28 & 817 & 183 \\
\hline
\end{tabular}

* The difference between manure from cattle and small ruminants to 1 kilogram is made up by manure from camels or donkeys. Values with different superscripts differ at $P \leqslant 0.05$; where no superscripts are given $P>0.05$. 
received the equivalent of about $1.4 \mathrm{~kg} \mathrm{day}^{-1}$ of millet grain for corralling services, which meets the daily food requirement of two adult persons.

The number of animals corralled ranged from 0.5 to 91.2 TLU per field, whereby the composition of herds varied widely. Pure herds of cattle, small ruminants and donkeys or camels were less frequent; the typical herd (TLU) consisted of 50\% cattle, $25 \%$ small ruminants and $25 \%$ donkeys or camels. Corralling was done without confining the animals on the field $(n=24)$, by tying the animals to poles $(n=13)$ or by building enclosures of branches $(n=2)$, whereby small ruminants tended to be tied and cattle tended to be left free.

Corralling started right after crop harvest $(n=29)$, or shortly after the start of the early dry season $(n=10)$; only one farmer declared that corralling of his particular field started in the late dry season. The main reason for the early start of corralling was the abundance of crop residues for livestock. The departure of the herd from the field was always determined by the livestock manager, the reason being mostly feed shortage $(n=26)$ or the start of field preparation for sowing $(n=8)$. Only in three cases (two transhumant herds, one household-managed herd) the herd departed when the required level of fertilisation was reached, but the three farmers did not specify how they assessed the latter criterion.

While three farmers stated that individual corrals were distributed evenly across the field, the remaining 37 farmers declared that the corrals covered particular spots within the field. Spots targeted preferentially were those of poor soil fertility $(n=20)$, micro-dunes $(n=7)$ and hardpans $(n=5)$. According to 25 farmers, the different spots were corralled for equal amounts of time. Nine farmers, however, declared that the dura-

Table 5

Parameters of the - transformed - exponential regression $Y=A \mathrm{e}^{B t}$ modeling the dry season disappearance of manure mass at corralled sites ( $Y$, $\mathrm{kg} \mathrm{DM} \mathrm{ha}^{-1}$ ) over time ( $t$, age of corrals in months from corral installation onwards) between February and July 1998 in the territory of Chikal/ Niger

\begin{tabular}{|c|c|c|c|c|c|c|c|}
\hline \multirow[t]{2}{*}{ Geomorph. unit } & \multirow[t]{2}{*}{ Corral no. } & \multirow[t]{2}{*}{ Initial age $^{\mathrm{a}}$ (months) } & \multicolumn{5}{|c|}{$\operatorname{Ln} Y=\ln A+B t$} \\
\hline & & & $A$ & $B$ & $r^{2}$ & $P_{\text {Model }} \leq{ }^{\mathrm{b}}$ & $P_{\mathrm{A}} \leq$ \\
\hline \multirow[t]{9}{*}{ Dallol } & 1 & 4 & 7.31 & -0.054 & 0.27 & 0.366 & 0.001 \\
\hline & 2 & 7 & 7.56 & -0.146 & 0.75 & 0.056 & 0.001 \\
\hline & 3 & 11 & 8.01 & -0.044 & 0.31 & 0.333 & 0.001 \\
\hline & 4 & 25 & 8.05 & -0.061 & 0.16 & 0.508 & 0.038 \\
\hline & 5 & 4 & 8.35 & -0.157 & 0.36 & 0.283 & 0.002 \\
\hline & 6 & 27 & 10.92 & -0.127 & 0.55 & 0.150 & 0.011 \\
\hline & 7 & 27 & 10.99 & -0.129 & 0.59 & 0.129 & 0.010 \\
\hline & 8 & 27 & 11.56 & -0.132 & 0.71 & 0.075 & 0.004 \\
\hline & 9 & 40 & 13.75 & -0.152 & 0.47 & 0.204 & 0.042 \\
\hline \multirow[t]{9}{*}{ Dune } & 1 & 4 & 8.17 & -0.162 & 0.33 & 0.312 & 0.003 \\
\hline & 2 & 4 & 8.19 & -0.108 & 0.61 & 0.122 & 0.001 \\
\hline & 3 & 2 & 8.40 & -0.151 & 0.56 & 0.145 & 0.001 \\
\hline & 4 & 15 & 8.73 & -0.123 & 0.49 & 0.190 & 0.007 \\
\hline & 5 & 4 & 8.85 & -0.095 & 0.68 & 0.087 & 0.001 \\
\hline & 6 & 29 & 10.38 & -0.113 & 0.46 & 0.212 & 0.020 \\
\hline & 7 & 28 & 11.55 & -0.122 & 0.57 & 0.142 & 0.001 \\
\hline & 8 & 15 & 12.63 & -0.336 & 0.90 & 0.014 & 0.002 \\
\hline & 9 & 28 & 13.20 & -0.189 & 0.35 & 0.297 & 0.065 \\
\hline \multirow[t]{7}{*}{ Pediments } & 1 & 3 & 7.69 & -0.256 & 0.78 & 0.046 & 0.001 \\
\hline & 2 & 3 & 8.02 & -0.099 & 0.61 & 0.118 & 0.001 \\
\hline & 3 & 2 & 8.20 & -0.168 & 0.94 & 0.006 & 0.001 \\
\hline & 4 & 4 & 8.45 & -0.168 & 0.52 & 0.169 & 0.001 \\
\hline & 5 & 1 & 8.61 & -0.157 & 0.84 & 0.028 & 0.001 \\
\hline & 6 & 3 & 9.70 & -0.198 & 0.88 & 0.018 & 0.001 \\
\hline & 7 & 15 & 9.91 & -0.115 & 0.83 & 0.032 & 0.001 \\
\hline
\end{tabular}

\footnotetext{
${ }^{\text {a }}$ Initial age: age at first sampling.

${ }^{\mathrm{b}} P_{\text {Model }}=P_{\mathrm{B}}$.
} 
tion of corralling varied for the different spots within a field. The decision on moving animals from one spot to another within the field was generally taken by the livestock manager and not by the farmer $(n=37)$; therefore, 19 farmers - among these all farmers to whom household members supplied corralling services - complained that not all of the spots that should be fertilized were actually corralled. On the other hand, 18 farmers - among these 10 farmers to whom transhumant herders supplied corralling serviceswere satisfied with the cover of spots by corrals within their field.

With 182 days ( $\pm 94, n=9$ ), herds managed by a member of the farmers' household spent significantly more time on a field than the 57 days $( \pm 73, n=9)$ of villagers' herds and the 33 days $( \pm 56.4, n=18)$ of transhumant herds. Within their respective periods of stay, transhumant herds moved on average 2.9 times $( \pm 3.27)$ and herds of villagers 4.1 times $( \pm 7.52)$ between different spots, whereas household herds moved 8.8 times $( \pm 3.11)$. The frequency of shifts of individual corrals was also related to the type of the targeted spot $(p<0.05)$, whereby most shifts occurred between spots of poor soil fertility and fewest shifts between spots covered by deep and loose sand (mirodunes). The duration of corralling a certain spot (days per corral) was, however, not related to the size of the individual corral. This indicated that even if animals were corralled for a longer period on a spot, the size of the corral remained unchanged. Corral size increased, however, with increasing number of livestock $(R=0.51, P<0.01, n=25)$.

While 15 farmers emphasized that there were no losses of manure after corralling until the start of field cultivation, 24 farmers observed manure losses, among whom 18 attributed the losses to the activity of termites, one to livestock passage and one to the effects of wind.

Asked about the benefits of corralling for the particular field, all farmers unanimously mentioned the good development of millet plants and the improvement of soil fertility.

\subsection{Resource endowment and manuring practices}

Households applying farmyard manure or corralling animals on their fields managed on average 3.0 $( \pm 1.15, n=66)$ plots compared to $2.5( \pm 1.23$, $n=42)$ plots of households applying neither of the two measures $(P<0.05)$. For the application of FYM but not for corralling, this was reflected in the results of the logistic regression where every additional plot managed increased the probability for FYM application by a factor of 2.4. The 40 households corralling their fields kept 1.9 TLU $( \pm 1.93)$ of small ruminants and 2.1 TLU $( \pm 2.18)$ of equines as compared to $1.0 \mathrm{TLU}( \pm 1.14)$ of small ruminants and 0.9 TLU ( \pm 0.94$)$ of equines kept by the 68 households not applying this measure $(P<0.01)$. Although the number of cattle was identical for both types of households (2.3 TLU \pm 3.48 ), the logistic regression indicated that the households' endowment with cattle slightly enhanced the probability of the application of corralling; however, the impact of the endowment with small ruminants on this decision was much stronger.

\subsection{Measured sizes of corralled and manured spots and amounts of dung applied}

In the 6 monitoring areas of $1 \mathrm{~km}^{2}$ each, 44 different spots that had been corralled and 13 spots where FYM had been hand spread were determined within the 9 months of observation. Out of the 44 corralled spots, 1 spot was detected at the second and 3 spots were detected at the third sampling date only;

Table 6

Seasonal and spatial variation in monthly manure dry matter disappearance rates $\left(\delta_{i j}\right)$ during five sampling periods* as determined for 25 corrals in Chikal/Niger between February and October 1998

\begin{tabular}{|c|c|c|c|c|c|c|c|}
\hline Parameter & $n$ & $\delta_{12}$ & $\delta_{23}$ & $\delta_{34}$ & $\delta_{45}$ & $\delta_{56}$ & $P \leq$ \\
\hline \multicolumn{8}{|c|}{ Corral emplacement } \\
\hline All units & 25 & $0.28^{\mathrm{a}}$ & $0.01^{\mathrm{c}}$ & $0.02^{\mathrm{bc}}$ & $0.09^{\mathrm{bc}}$ & $0.16^{\mathrm{ab}}$ & 0.001 \\
\hline allol & 9 & $0.32^{\mathrm{a}}$ & $0.08^{\mathrm{bc}}$ & $-0.07^{\mathrm{c}}$ & $0.00^{\mathrm{c}}$ & $0.22^{\mathrm{ab}}$ & 0.01 \\
\hline une & 9 & $0.28^{\mathrm{a}}$ & $0.00^{\mathrm{ab}}$ & $-0.03^{\mathrm{ab}}$ & $0.14^{\mathrm{ab}}$ & $0.03^{\mathrm{ab}}$ & 0.05 \\
\hline ediments & 7 & $0.24^{\mathrm{a}}$ & $-0.07^{\mathrm{b}}$ & $0.19^{\mathrm{a}}$ & $0.16^{\mathrm{a}}$ & $0.24^{\mathrm{a}}$ & 0.05 \\
\hline \multicolumn{8}{|c|}{ Age at first sampling } \\
\hline$\leq 10$ months & 13 & $0.30^{\mathrm{a}}$ & $-0.08^{\mathrm{c}}$ & $0.09^{\mathrm{bc}}$ & $0.14^{\mathrm{ab}}$ & $0.22^{\mathrm{ab}}$ & 0.001 \\
\hline 10 months & 12 & $0.27^{\mathrm{a}}$ & $0.11^{\mathrm{ab}}$ & $-0.07^{\mathrm{b}}$ & $0.04^{\mathrm{b}}$ & $0.09^{\mathrm{ab}}$ & 0.05 \\
\hline \multicolumn{8}{|c|}{$\begin{array}{l}\text { * Monthly loss of manure dry matter between sampling } i \text { and } j \\
\text { lative to initial amount; } t \text { : days elapsed between sampling } i \text { and } j \text { : } \\
\left.\left.\mathrm{DM}_{i}-\mathrm{DM}_{j}\right) / \mathrm{DM}_{i}\right] /(t / 30) ; \delta_{12}: \text { February-March, } \delta_{23} \text { : March- } \\
\text { pril, } \delta_{34} \text { : April-June, } \delta_{45}: \text { June-July, } \delta_{56}: \text { July-October. Within } \\
\text { ws, values with different superscripts differ at the indicated level } \\
\text { probability. }\end{array}$} \\
\hline
\end{tabular}


the manually manured sites (FYM spots) were all detected at the first sampling date. The average size and age of manually manured spots at the moment of detection was $159 \mathrm{~m}^{2}( \pm 361.8)$ and 3.8 months ( \pm 2.5$)$, respectively. The share of cattle faeces in the manure mixture deposited on FYM spots was $68.5 \%( \pm 39.03)$, the share of small ruminant faeces averaged $23.5 \%( \pm 37.16)$. The total amount of manure deposited on FYM spots ranged from 0.06 to $7.56 \mathrm{~kg} \mathrm{DM} \mathrm{m} \mathrm{m}^{-2}$. After correction for sand adhering to the manure samples, the amount of organic matter applied to manually manured spots was $2.02 \mathrm{~kg} \mathrm{OM} \mathrm{m}^{-2}( \pm 1.391)$.

With the exception of one very large spot of $41,775 \mathrm{~m}^{2}$, the size of corralled spots ranged from $419-21,344 \mathrm{~m}^{2}$ with an average of $4434 \mathrm{~m}^{2}$
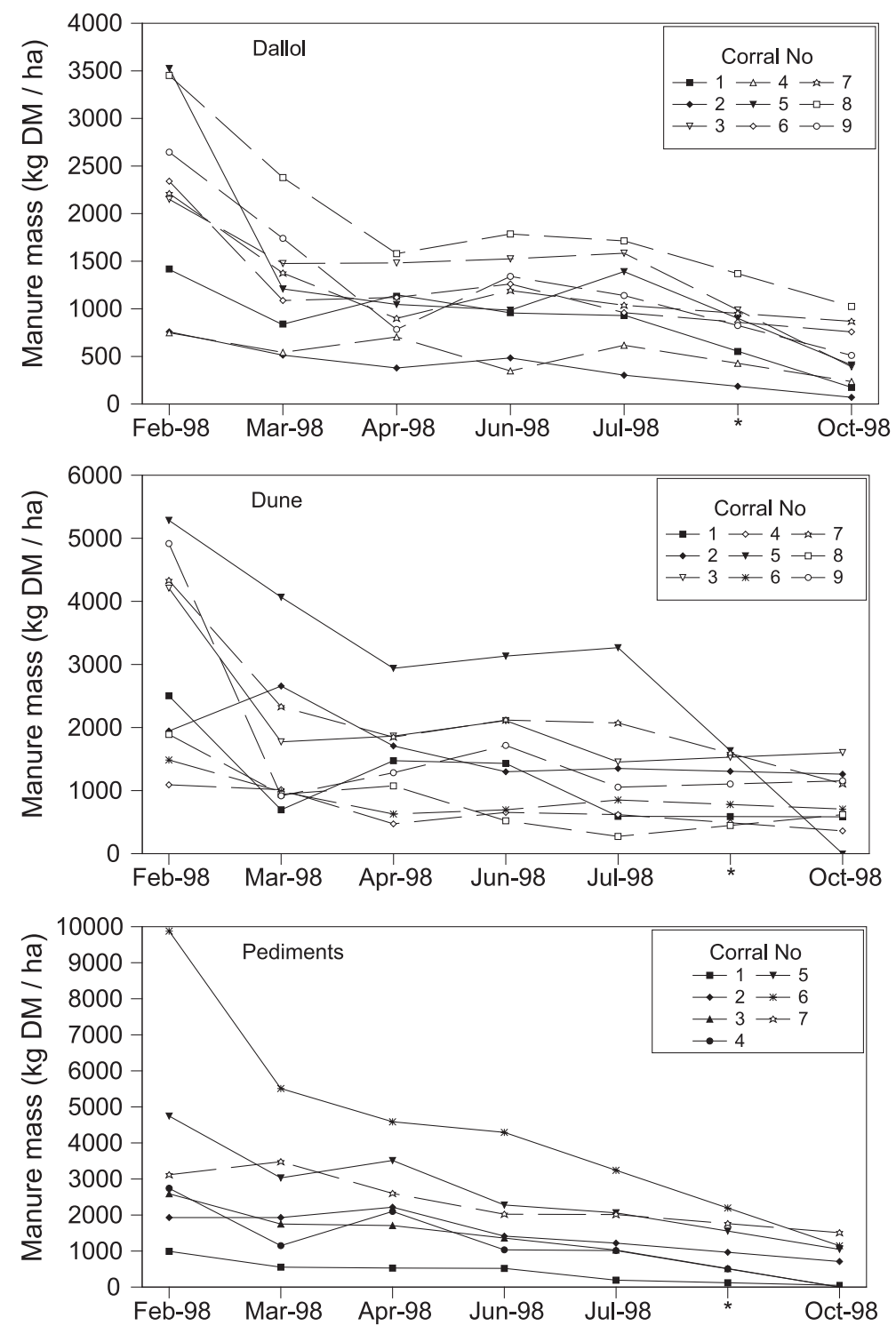

Fig. 2. Disappearance of manure dry matter on corralled spots determined within two $1-\mathrm{km}^{2}$ sampling sites at three different geomorphologic units in Chikal/Niger between February and October 1998. Note: $y$-axes have different scales. *Calculated values. 
( $\pm 4597.9, n=35$ ). Spots predominantly manured by cattle $(n=27)$ and equines or camels $(n=5)$ had an average size of 4534 and $4513 \mathrm{~m}^{2}$, respectively, spots predominantly manured by small ruminants $(n=3)$ had an average size of $3405 \mathrm{~m}^{2}$. The age of the corralled spots at the moment of detection averaged 10.8 months $( \pm 11.7, n=44$; Table 5). The share of cattle faeces in the manure mixture deposited in corrals (Table 4) strongly influenced the total amount of faeces quantified at all sampling dates $(P<0.001)$.

The geomorphology of the corralled sites did not influence the slope and intercept of the manure decay curves (Table 5): across the 25 corrals for which complete data sets were obtained, the intercept $(A)$ averaged 9.61, 10.01 and 8.65 and the slope $(B)$ $-0.111,-0.155$ and -0.166 for the Dallol $(n=9)$, the Dune $(n=9)$ and the Pediments $(n=7)$. The age of the corral at 1st sampling influenced the intercept but not the slope of the regressions, with younger corrals ( $<10$ months) having a lower intercept $(8.27, n=13$ ) than older corrals $(10.81, n=12 ; P<0.001)$. Significant differences in the manure disappearance rates of individual periods occurred for each of the three geomorphologic units (Table 6). During April-June, the manure disappeared faster on Pediments than in the Dallol $(P<0.05)$ and, during July-October, manure disappearance on Pediments and in the Dallol was faster than on the Dune sites $(P<0.05)$. During the latter period, manure disappearance was also higher on younger than on older corrals $(P<0.05)$, whereas during all other periods the age of the corral did not affect the monthly disappearance rate (Fig. 2).

\section{Discussion}

The present study concentrated on farmers' fertility management of well-defined individual fields and only the measures applied during the dry season in which the interview was held were considered. This allowed avoiding generalizing statements about farmers' fertility management such as reported in previous studies (Bationo and Mokwunye, 1991; Powell and Williams, 1993; Sterk and Haigis, 1998; Schlecht et al., 2001a; Wezel and Haigis, 2002), which tended to overestimate the application of practices such as mulching or manuring.

\subsection{Fallowing practices}

Recent research has shown some of the causes for the often observed fallow effects on acid sandy Sahelian soils. These are related to nutrient inputs from leaf fall, biological $\mathrm{N}_{2}$ fixation from fallow legumes and improved $\mathrm{P}$ and $\mathrm{K}$ availability via the deposition of dust with its high base saturation (Stahr and Herrmann, 1996; Buerkert and Hiernaux, 1998). If only nutrients exported in cereal grain are accounted for, the amounts of nutrients exported from a millet field after a 3-year cropping cycle can be replenished by a 2-year fallow period. However, if an adjustment is made for livestock consumption or export of crop residues and increased soil erosion under millet cultivation, 6-12 years of fallow are needed to restore the nutrient losses of a 3-year cropping period (Herrmann, 1996; van Duivenbooden, 1996). In $1997 / 1998$, only $11 \%$ of the monitored fields in Chikal had been completely fallowed for 5 or more years, whereas another $40 \%$ of the fields had been partially fallowed for an average of 6 years on approximately $45 \%$ of their surface. These survey figures correspond closely to the fallow/cropland coefficient of 0.55 that was calculated from a land use map of Chikal territory established for 1997/1998 (Schlecht et al., 2001a). They are also consistent with the observation that nearly $30 \%$ of farmers in western Niger permanently cultivate their fields and less than $10 \%$ of farmers fallow fields for more than 5 years (Wezel and Haigis, 2002). The decline in the installment of complete fallows and the high proportion of partial fallows point to a decreasing availability of arable land within the territory of Chikal. In the Dallol, where the cropping intensity is highest (see Section 2), fields were subjected to partial fallow much more frequently than fields located on the other geomorphologic units. Farmers' obviously perceived the need to restore soil fertility on these intensely cropped plots and tried to overcome the scarcity of alternative cropland in this way.

\subsection{Burning and mulching of plant material}

The fact that the practice of crop residue burning is not that widespread in Chikal is due to the efforts of several projects (Zada, 1999), which, according to the farmers, advised against burning of crop residues. 
Reportedly, only $3.6 \%$ of the fields included in the survey were burned. In contrast to this, results of a smaller survey on the management of fields that were not included in the present sample indicated that on approximately $30 \%$ of all fields remaining millet stalks along with branches and unearthed rootstocks were burned the during April to June to facilitate seeding, which is also reported by Bationo and Mokwunye (1991) and Hoffmann et al. (2001). The divergence between the two sets of responses obtained for Chikal might be due to the fact that, when the first part of the detailed interviews was held (January/ February), the farmers had not yet decided on burning the mulch.

Precise figures on the amounts of material burned are lacking. The burning of $2000 \mathrm{~kg} \mathrm{DM} \mathrm{ha}{ }^{-1}$ of millet residues resulted in lower biomass and grain yields of millet and weeds compared to a broadcast application of crop residue at $500 \mathrm{~kg} \mathrm{DM} \mathrm{ha}{ }^{-1}$ (Muehlig-Versen et al., 1997). This can particularly be attributed to combustion and volatilization of carbon and nitrogen during burning and to a deterioration of structural, physical and chemical soil properties through ash as compared to mulch application (Buerkert et al., 2000). Therefore, only minor increases in millet biomass and grain yields can be expected from farmers' practice of burning at most $650 \mathrm{~kg} \mathrm{ha}^{-1}$ of crop residue, which is reflected in the farmers' insistence on the short-term effects of burning on soil fertility.

The application of crop residue mulch during the dry season is a method frequently advocated in the Sahel (Bationo et al., 1995; Buerkert and Lamers, 1999). Major benefits of crop residue application to the sandy acid soils of the region as reviewed by Buerkert et al. (2000) are improvement of soil macro-structure, improved water infiltration and increased water holding capacity, reduced wind and water erosion, improved soil cation exchange capacity, supply of slowly released plant nutrients, and chelation of phosphorus fixed by aluminum and iron-oxides. However, only $36 \%$ of the fields covered by the present study were purposefully mulched in the 1997/1998 dry season, which is considerably lower than the $84 \%$ of mulched fields reported from a previous survey on the general practices of soil fertility management (Schlecht et al., 2001a). The modest application of mulching practices and prevalent renouncement of burning practices reflects the scarcity of crop residues in the arid Chikal territory with its low millet yields and the important alternative uses of millet residues such as building purposes and livestock fodder (Lamers and Feil, 1995). This is also reflected in the low amounts of $50-630 \mathrm{~kg} \mathrm{DM} \mathrm{ha}^{-1}$ of crop residues remaining on the field surface in mid and late dry season (Schlecht et al., 2001a), although according to farmers' estimates the initial amounts applied were in the range of $1000-3000 \mathrm{~kg}$ DM $\mathrm{ha}^{-1}$. The losses of crop residue mulch were thus presumably higher than the estimated $43 \%$. The activity of termites, which farmers held primarily responsible for the disappearance of mulch material as well as of dung, was reported to intensify only in the late dry season (Esse et al., 2001; Léonard and Rajot, 2001), while intense livestock grazing on millet fields prevails in the early dry season (Schlecht et al., in press). About $50 \%$ of the dry matter and $80 \%$ of the nitrogen and phosphorus ingested by livestock is returned to the fields through voiding of faeces and urine during grazing (Schlecht et al., in press). Therefore, the disappearance of mulch has presumably more pronounced consequences for soil erosion than for the soil nutrient status. Although moderate residual effects of residue mulch on millet biomass yields were determined for up to four cropping periods in a greenhouse experiment (Powell et al., 1999), farmers apply mulch every year. The high application frequency supports the farmers' statement that mulching is primarily undertaken to fight the negative effects of erosion.

\subsection{Application of farmyard manure}

Only $16 \%$ of the investigated fields in Chikal received FYM. This proportion is much lower than those previously reported for areas receiving an annual precipitation of over $500 \mathrm{~mm}$ year $^{-1}$ of rain (Harris and Yusuf, 2001; Hoffmann et al., 2001; Osbahr and Allan, 2003). Although the problem of manure transport was mentioned by only one farmer, the low availability of donkey carts in Chikal territory (own observation and Haigis, pers. comm.) might be partly responsible for the low proportion of manually manured fields, because transport of dung in baskets 
on donkeys is not practiced in this area. On the other hand, the results of the logistic regression analysis indicated that the probability of manuring was higher for distant fields than for fields close to settlements. This was confirmed in the monitoring of the $1-\mathrm{km}^{2}$ large areas, where heaps of FYM were only encountered at more than $5 \mathrm{~km}$ from the village. This might be due to the fact that animals can be protected from theft more effectively close to the homesteads, which greatly enhances the chance of village fields to be corralled by sedentary livestock (Hiernaux et al., 1998; Schlecht et al., 2001a).

The applied amount of $145 \mathrm{~kg} \mathrm{ha}^{-1}$ of FYM derived from farmers' records is low when compared to amounts reported from Northern Nigeria (Harris and Yusuf, 2001; Hoffmann et al., 2001). However, when related to the part of the field where FYM was actually concentrated (on average 2.5 ha of a 10.8-ha field), an application rate of $630 \mathrm{~kg}$ of FYM per manured spot was calculated from farmers' accounts. The average value of $3.6 \mathrm{~kg} \mathrm{DM} \mathrm{m}^{-2}$ measured on FYM spots translated to $572 \mathrm{~kg}$ DM per spot when the average size of $159 \mathrm{~m}^{2}$ of FYM spots was accounted for. The good agreement between amounts of manure calculated from farmers' information and measured quantities support approaches where estimates of manure quantities are entirely based on farmers' accounts (Hoffmann et al., 2001; Osbahr and Allan, 2003). With nitrogen $(\mathrm{N})$ and phosphorous (P) contents of $12-15 \mathrm{~g} \mathrm{~N}$ and $2.0-2.2 \mathrm{~g} \mathrm{P} \mathrm{kg}^{-1} \mathrm{DM}$ in farmyard manure from cattle and small ruminants (Esse et al., 2001), the FYM applied to a particular spot should have provided 8-10 times the amount of $\mathrm{N}$ and 18 times the amount of $\mathrm{P}$ taken up annually by millet plants under the cropping conditions prevailing in the Chikal area (Esse et al., 2001). They could thus provide residual fertilizing effects for at least two subsequent cropping seasons (Powell et al., 1998), and point to the possible extension of manuring intervals from presently $1-2$ to 3 years, which would increase the area benefiting from this measure. In southern Niger with annual rainfall exceeding 500 $\mathrm{mm}$ a comparable oversupply of nutrients to sandy soils may still be temporarily exacerbated by the slow shoot development and nutrient uptake of millet seedlings during the first 6 weeks of growth (Hafner et al., 1993) and likely causes considerable $\mathrm{N}$ losses by leaching below the rooting zone of millet. However, this risk is evidently smaller in the $350-\mathrm{mm}$ rainfall zone at Chikal. There lateral removal of nutrients by surface runoff or wind erosion, particularly on pediment sites with a crusted topsoil and poor plant growth seem more severe, even if it may at the watershed level merely lead to a transfer of nutrients to nearby deposition sites (Buerkert and Hiernaux, 1998).

Similar to farmers in the Kano close settled zone (Harris and Yusuf, 2001), the majority of farmers in Chikal spread FYM in the early or mid-dry season in order to assure an eolian sand cover of the spots and to minimize losses of the applied material. The effectiveness of this strategy is reflected in the poor recovery of FYM after the first sampling date within the $1-\mathrm{km}^{2}$ monitoring areas. Farmers emphasized the sand-capturing characteristic of FYM as a further benefit of its application, that is the additional deposit of nutrients, especially potassium, calcium and magnesium, but also $\mathrm{N}$ and $\mathrm{P}$ (Herrmann, 1996) on the manured spot.

\subsection{Corralling livestock on cropland}

To exploit the additional benefits of urine and to minimize nutrient losses, corralling livestock on fields is preferable to the application of farmyard manure (Powell et al., 1998). About 13\% of the surveyed fields were reportedly corralled in the 1997/1998 dry season. Similarly to the situation in northern Nigeria (Hoffmann et al., 2001), transhumant herds supplied the corralling service for more than half of the corralled fields in the territory of Chikal. This highlights the role of these mobile herds for maintaining soil fertility in the mixed crop-livestock systems of West Africa (Heasley and Delehanty, 1996; Schlecht et al., 2001b). Despite this, only six formal corralling contracts were established and, among these, there were only two with transhumant herders. While corralling contracts are indispensable in northern Nigeria (Hoffmann and Mohammed, accepted), the situation in Chikal may reflect the eroding relationships between sedentary crop-livestock farmers and transhumant herders (Neef, 1998; Turner, 1999). The high involvement of transhumant herds in corralling but concomitantly eroding relationships between sedentary and mobile communities may also explain the observation that corrals - namely those of transhu- 
mant herds - were primarily established on remote fields. The deterioration of social bonds is further reflected by the high proportion of farmers who contact different herders for corralling services in subsequent years.

Feed availability for livestock herds was mentioned as the main determinant for the onset of corralling, which was mostly decided on by the livestock herders. Therefore, suggestions derived from agronomic trials to minimize organic matter and nutrient losses by corralling fields late in the dry season or at the onset of the rainy season (Somda et al., 1995) can hardly be realized in the Chikal area. Similarly, suggestions on the amount of manure to be deposited on corralled fields to minimize nutrient losses (Brouwer and Powell, 1998) and maximize yield returns to the scarce resource (Schlecht et al., in press) remain academic if the duration of corralling is not determined by the amount of dung deposited on the field but mainly depends on nearby feed availability. However, in general, the initial amounts of manure applied through corralling in Chikal are consistent with the amounts recommended by Brouwer and Powell (1998), although wide variations were observed. The comparison of the amounts of manure on corralled sites within the $1-\mathrm{km}^{2}$ monitoring areas with the values estimated from farmers' accounts revealed a good agreement when these estimates were based on the numbers of livestock corralled. Attempts to derive amounts of dung per hectare from farmers' estimates of corral sizes completely failed, although a known unit for corral size (multiples of a round-hut) was used. This indicates that socio-pedological inquiries need verification of farmers' ability to estimate or evaluate parameters relevant to the respective study.

The farmers' assertion that on average a field is corralled every second year points to a high corralling frequency compared to other villages in the region (Schlecht et al., in press). But it contradicts information about the age of corrals given in the context of the monitoring of manure disappearance rates, from where an average corralling interval of 3-5 years was derived. Since the residual effect of manure application through corralling lasts for three to five cropping seasons (Schlecht et al., in press), a high frequency of corralling induces a waste of nutrients. As for the application of FYM, a lowered corralling frequency per area offers possibilities to extend the spatial coverage of this measure.

\subsection{Decay of manure on corralled sites}

On the regularly monitored corralled sites, faeces or disintegrated faecal particles that had moved deeper than $1 \mathrm{~cm}$ into the soil, either through action of mesofauna or livestock trampling, were not retrieved but considered as disappeared. This does not necessarily imply that they were decomposed or mineralized. Moreover, disintegrated faecal particles of less than 2-mm size were not retrieved by the manual sampling technique, even if they had remained at the soil surface.

Despite the fact that in controlled trials on manure decay and mineralization faeces of small ruminants resisted more to breakdown than cattle manure (Powell et al., 1998), the situation encountered on corralled spots was different. The large surface of moist cattle faeces hardens rapidly when drying at the prevailing high ambient temperatures. Thus, faeces of cattle often appeared to be intact for a long time, but, when they were turned over, they were found to be totally hollow inside, reflecting the activity of mesofauna. Although equine faeces contain longer fibers than faeces of cattle and small ruminants, they disintegrate- but not necessarily decompose (Hoffmann et al., 2001) - more quickly due to their lower moisture content. Faeces of camels contain again less water than faeces of cattle and small ruminants and also disintegrate faster. Although the small faeces of sheep and goats do not disintegrate nor decompose quickly (Hoffmann et al., 2001), they are easily covered with sand and thus disappear from the soil surface.

The fact that manure disappearance in the early dry season (February-April) was highest might to a considerable extend be due to the aforementioned phenomena of physical disintegration, sand coverage and limited termite activity. Less than $15 \%$ of the initially determined dung disappeared in the period March-July. This is in agreement with the findings of Somda et al. (1995) and Powell et al. (1998). For the corrals located on the Dune, no disappearance of dung was measured after April. This was most likely because dung was incorporated into the upper soil layers. Manure decay in the Dallol and on Pediments rose greatly during the rainy season (July-October), 
which is confirmed by the results of controlled manure decomposition trials carried out at the same sites (Esse et al., 2001). The important manure decomposition during the rainy season points to a synchronized nutrient supply to the millet crop irrespective of the early start of corralling through the herders (see Section 5.4).

The slope of the transformed equations on manure disappearance was similar for corrals of different age. This might be due to the fact that faeces on older corrals were already in a more disintegrated stage compared to recently deposited faeces. Yet, a quick decay would be expected for the easily degradable components of newly deposited manure, whereas the material on old corrals should primarily consist of the remaining slow decay fraction (Somda et al., 1995). However, the similar disappearance kinetics might suggest that older corrals contained a considerable proportion of newly deposited manure. Successive corral enlargement in subsequent years could also explain the sometimes considerable sizes of older corral sites of $2-4$ ha such as found in Chikal. However, due to the manure sampling approach used for corralled sites, it was not possible to distinguish between younger and older parts or faeces, respectively.

Regression equations on manure disappearance with a regression coefficient above 0.5 predicted a quicker disappearance of manure than equations with a poor fit. This points to the fact that the exponential model used explained rapid manure disappearance rates better than slower disappearance rates. In this context it is noteworthy that two compartmental pool models for faecal components of quick and slow decay as used by Somda et al. (1995) could not to be fitted successfully to the data set available for corrals in Chikal.

\subsection{Soil fertility measures-targeted and resource- dependent}

The farmers' intention to mulch, manually manure or corral particular spots within the field fits into the general picture of targeted soil fertility management. The combined application of mulch and manure-by manual application or corralling - to different spots within the same field was acknowledged for 36 fields; in 3 cases, a field was simultaneously manured and corralled and, on 9 fields, all three measures were applied simultaneously. The three measures were directed to spots of poor soil productivity in the first place and secondly to hardpans (see Sections 4.2, 4.3 and 4.4). For FYM application, this differentiation could be due to the fact that the powdered manure is more easily blown off the smooth surface of hardpans. The beneficial effects of crop residue mulch, however, are stronger on hardpans than on loose soils as has been demonstrated by research under controlled conditions. This is due to the higher occurrence of termites on hardpans, which leads to better root growth and water infiltration on the termite-loosened soil (Buerkert et al., 1995; Léonard and Rajot, 2001).

The access to resources proved to be important for the application of dung through corralling or manual application. This was reflected by the high odds ratios obtained for the endowment with small ruminants, land and cattle. More than $80 \%$ of the farmers who had their fields corralled paid for the supply of corralling services. The remuneration equaled the average monthly salary of a day-worker in the village at the period of study, and the farmers evoked lack of (financial) resources to pay for corralling services as the main difficulty in applying this measure. Even for the implementation of a complete fallow, the farmer's endowment with land and, to a less extend endowment with cattle, was decisive according to the results of the logistic regression. This indicates that only farmers who have ample cropland to produce food for auto-consumption or who can manure their fields are able to apply a complete fallow because they have means to substitute the yield from the fallowed field.

Mulching and manure application by hand or by corralling was combined with partial fallow on 76 fields. While the high use of partial fallow points to the awareness of decreasing land availability, the fact that 104 of the 108 households owned livestock but only 48 applied FYM and only 18 relied on village animals for corralling services points to a neglect of the available manure resources. Based on established values (Schlecht et al., 1998) and the average number of TLU, an amount of $2000 \mathrm{~kg}$ fecal dry matter per household and year is deposited at the night enclosure, which, at a three-yearly manuring interval and an application rate of $3 \mathrm{t} \mathrm{ha}^{-1}$ (Brouwer and Powell, 1998), would allow to fertilize 0.6 ha of cropland per household and year. 


\section{Conclusions}

The data of the present study conducted in a more arid part of the Sahel indicate that soil fertility measures applied to millet fields are carefully targeted to particular spots within fields. Farmers primarily aim at improving crop yields on spots that are considered degraded and at fighting wind erosion. While the widespread application of complete fallows and crop residue mulch are difficult due to lack of land and alternative uses of the straw, respectively, livestock dung is not exploited to its full extend in the studied region, neither in terms of the quantity presently available for manuring nor in terms of its residual fertilizing effect. The small sizes of individually owned herds, fear of livestock theft and lack of transport for substantial amounts of farmyard manure might be hindrances for a more efficient use of corralling and manual manuring, respectively. The use of donkey baskets as practiced in northern Nigeria (Hoffmann et al., 2001) and the organization of communal corralling as practiced in Mali (Dembélé et al., 2000) could help to overcome these bottlenecks. Although determinants of soil fertility management such as personal interest in innovation, cash income of households and security of landholdings were not covered by the present study, the endowment with livestock and land appeared to be crucial for the soil fertility management of individual households. Therefore, complementary strategies have to be encouraged particularly for poor farmers, if the rapid decline of soil fertility and out-migration of families from the more arid regions of the Sahel is to be counteracted. Together with the partial fallowing of fields, the enhanced application of leaves and small branches of shrubs as mulching material (Wezel and Boecker, 1999) might be one option in this respect. If mineral fertilizer is available, the placed application of small doses of this amendment should also be promoted (Buerkert and Hiernaux, 1998).

\section{Acknowledgements}

The authors sincerely appreciate the significant contribution of I. Altine, A. Agali, H. Kolokoye and A. Moussa, the field assistants in Chikal, to the success of the interviews and manure measurements in the field, and are indebted to all interviewed farmers for their great patience with the inquiries. Special thanks are due to P. Hiernaux and C. Freitag for their most valuable advice on data analysis and to M. Slingerland and A. Wezel for their helpful comments on the first version of the manuscript. The financial support through Deutsche Forschungsgemeinschaft (DFG) in the framework of SFB 308 is gratefully acknowledged.

\section{References}

Bationo, A., Mokwunye, A.U., 1991. Role of manure and crop residues in alleviating soil fertility constraints to crop production: with special reference to the Sahelian and Soudanian zones of West Africa. Fertilizer Research 29, 117-125.

Bationo, A., Christianson, B.C., Klaij, M.C., 1993. The effect of crop residue and fertilizer use on pearl millet yields in Niger. Fertilizer Research 34, 251-258.

Bationo, A., Buerkert, A., Sedogo, M.P., Christianson, B.C., Mokwunye, A.U., 1995. A critical review of crop residue use as soil amendment in the West African semi-arid tropics. In: Powell, J.M., Férnandez-Rivera, S., Williams, T.O., Renard, C. (Eds.), Livestock and Sustainable Nutrient Cycling in Mixed Farming Systems of Sub-Saharan Africa. Technical Papers, vol. II. ILCA, Addis Ababa, Ethiopia, pp. 305-322.

Brouwer, J., Powell, J.M., 1998. Increasing nutrient use efficiency in West-African agriculture: the impact of micro-topography on nutrient leaching from cattle and sheep manure. Agriculture, Ecosystems and Environment 71, 229-239.

Buerkert, A., Hiernaux, P., 1998. Nutrients in the West African Soudano-Sahelian zone: losses, transfers and role of external inputs. Zeitschrift für Pflanzenernährung und Bodenkunde 161, 365-383.

Buerkert, A., Lamers, J.P.A., 1999. Soil erosion and deposition effects on surface characteristics and pearl millet growth in the West African Sahel. Plant and Soil 215, 239-253.

Buerkert, A., Stern, R.D., Marschner, H., 1995. Post stratification clarifies treatment effects on millet growth in the Sahel. Agronomy Journal 87, 752-761.

Buerkert, A., Mahler, F., Marschner, H., 1996. Soil productivity management and plant growth in the Sahel: potential of an aerial monitoring technique. Plant and Soil 180, 29-38.

Buerkert, A., Bationo, A., Dossa, K., 2000. Mechanisms of residue mulch-induced cereal growth increases in West Africa. Journal of the Soil Science Society of America 64, 346-358.

Casenave, A., Valentin, C., 1989. Les états de surface de la zone sahélienne. Influence sur l'infiltration. ORSTOM, Paris. 229 pp.

Dembélé, I., Koné, D., Soumaré, A., Coulibaly, D., Koné, Y., Ly, B., Kater, L., 2000. Fallows and field systems in dryland Mali. In: Hilhorst, T., Muchena, F.M. (Eds.), Nutrients on the MoveSoil Fertility Dynamics in African Farming Systems. International Institute for Environment and Development, London, UK, pp. $83-102$. 
Esse, P.C., Buerkert, A., Hiernaux, P., Assa, A., 2001. Decomposition of and nutrient release from ruminant manure on acid sandy soils in the Sahelian zone of Niger, West Africa. Agriculture, Ecosystems and Environment 83, 55-63.

FAO, 2002. FAO Statistical Databases. http://www.fao.org/.

Hafner, H., George, E., Bationo, A., Marschner, H., 1993. Effect of crop residues on root growth and nutrient acquisition of pearl millet in an acid sandy soil in Niger. Plant and Soil 150, 117-127.

Harris, F., Yusuf, M.A., 2001. Manure management by smallholder farmers in the Kano close settled zone, Nigeria. Experimental Agriculture 37, 319-332.

Heasley, L., Delehanty, J., 1996. The politics of manure: resource tenure and the agropastoral economy in southwestern Niger. Society and Natural Resources 9, 31-46.

Herrmann, L., 1996. Staubdeposition auf Boeden West-Afrikas. Eigenschaften und Herkunftsgebiete der Stäube und ihr Einfluss auf Boden und Standortseigenschaften. Hohenheimer Bodenkundliche Hefte 36 University of Hohenheim, Stuttgart, Germany. 239 pp.

Hiernaux, P., Fernández-Rivera, S., Schlecht, E., Turner, M.D., Williams, T.O., 1998. Livestock-mediated nutrient tranfers in Sahelian agro-ecosystems. In: Renard, G., Neef, A., Becker, M., von Oppen, M. (Eds.), Soil Fertility Management in West African Land Use Systems. Margraf Verlag, Weikersheim, Germany, pp. 339-347.

Hoffmann, I., Mohammed, I., accepted. The role of nomadic camels for manuring farmers' fields in the Sokoto Close Settled Zone, Northwest Nigeria. Nomadic Peoples.

Hoffmann, I., Gerling, D., Kyiogwom, U.B., Mané-Bielfeldt, A., 2001. Farmers' management strategies to maintain soil fertility in a remote area in northwest Nigeria. Agriculture, Ecosystems and Environment 86, 263-275.

Ikpe, F.N., Powell, J.M., Isirimah, N.O., Wahua, T.A.T., Ngodigha, E.M., 1999. Effects of primary tillage and soil amendment practices on pearl millet yield and nutrient uptake in the Sahel of West Africa. Experimental Agriculture 35, 437-448.

Lamers, J.P.A., Feil, P., 1995. Farmer's knowledge and management of spatial soil and crop growth variability in Niger, West Africa. Netherlands Journal of Agricultural Science 43, 375-389.

Léonard, J., Rajot, J.L., 2001. Influence of termites on runoff and infiltration: quantification and analysis. Geoderma 104, 17-40.

McIntire, J., Bourzat, D., Pingali, P., 1992. Crop-Livestock Interaction in Sub-Saharan Africa. The World Bank, Washington, DC. 246 pp.

Muehlig-Versen, B., 2001. Effects of crop residue management, phosphorus application and molybdenum supply on yield and nutrient uptake of pearl millet, cowpea and groundnut in Sahelian cropping systems. PhD thesis, University of Hohenheim, Verlag U.E. Grauer, Beuren-Stuttgart, Germany.

Muehlig-Versen, B., Buerkert, A., Bationo, A., Marschner, H., 1997. Crop residue and phosphorus management in millet based cropping systems on sandy soils of the Sahel. In: Renard, G., Neef, A., Becker, K., von Oppen, M. (Eds.), Soil Fertility Management in West African Land Use Systems. Margraf Verlag, Weikersheim, Germany, pp. 31-40.

Neef, A., 1998. Le contrat de parcage, fumure pour les riches? Une étude de cas au sud-ouest du Niger. In: Renard, C., Neef, A.,
Becker, K., von Oppen, M. (Eds.), Soil Fertility Management in West African Land Use Systems. Margraf Verlag, Weikersheim, Germany, pp. 381-386.

Osbahr, H., Allan, C., 2003. Indigenous knowledge of soil fertility management in southwest Niger. Geoderma 111, 457-479.

Powell, J.M., Williams, T.O., 1993. Livestock, nutrient cycling and sustainable agriculture in the West African Sahel. International Institute for Environment and Development, London, UK. Gatekeeper Series No. SA37. 15 pp.

Powell, J.M., Ikpe, F.N., Somda, Z.C., Fernández-Rivera, S., 1998. Urine effects on soil chemical properties and the impact of urine and dung on pearl millet yield. Experimental Agriculture 34, 259-276.

Powell, J.M., Ikpe, F.N., Somda, Z.C., 1999. Crop yield and the fate of nitrogen and phosphorus following application of plant material and feces to soil. Nutrient Cycling in Agroecosystems 54, 215-226.

SAS, 2000. SAS/STAT Users Guide, Version 8 Vol II. SAS Institute, Cary, NC.

Schlecht, E., Fernández-Rivera, S., Hiernaux, P., 1998. Timing, size an N-concentration of faecal and urinary excretions in cattle, sheep and goats - can they be used for better manuring of cropland? In: Renard, G., Neef, A., Becker, K., von Oppen, M. (Eds.), Soil fertility management in West African land use systems. Margraf Verlag, Weikersheim, Germany, pp. $361-368$.

Schlecht, E., Kadaouré, I., Graef, F., Huelsebusch, C., Mahler, F., Becker, K., 2001a. Land use and agricultural practices in the agro-pastoral farming systems of western Niger-a case study. Die Erde 132, 399-418.

Schlecht, E., Hiernaux, P., Turner, M.D., 2001b. Mobilité du bétail: nécessité et alternatives. In: Tielkes, E., Schlecht, E., Hiernaux, P. (Eds.), Elevage, gestion des parcours et Implications pour le Développement au Sahel. Verlag U.E. Grauer, Beuren-Stuttgart, Germany, pp. 65-77.

Schlecht, E., Hiernaux, P., Achard, F., Turner, M.D., in press. Livestock related nutrient budgets within village territories in western Niger. Accepted by Nutrient Cycling in Agroecosystems (in press).

Scoones, I., Toulmin, C., 1998. Soil nutrient budgets and balances: what use for policy? Agriculture, Ecosystems and Environment 71, 255-267.

Somda, Z.C., Powell, J.M., Fernández-Rivera, S., Reed, J., 1995. Feed factors affecting nutrient excretion by ruminants and the fate of nutrients when applied to soil. In: Powell, J.M., Férnandez-Rivera, S., Williams, T.O., Renard, C. (Eds.), Livestock and Sustainable Nutrient Cycling in Mixed Farming Systems of Sub-Saharan Africa. Technical Papers, vol. 11. ILCA, Addis Ababa, Ethiopia, pp. 227-243.

Stahr, K., Herrmann, L., 1996. Origin, deposition, and composition of dust, and consequences for soil and site properties with special reference to the semi-arid regions of West Africa. In: Buerkert, B., Allison, B.E., von Oppen, M. (Eds.), Wind Erosion in Niger. Implications and Control Measures in a Millet-Based Farming System. Developments in Plant and Soil Sciences, vol. 67. Kluwer Academic Publishing, Amsterdam, The Netherlands, pp. 45-65. 
Sterk, G., Haigis, J., 1998. Farmers' knowledge of wind erosion processes and control methods in Niger. Land Degradation and Development 9, 107-114.

Stoorvogel, J.J., Smaling, E.M.A., Janssen, B.H., 1993. Calculating soil nutrient balances in Africa at different scales: I. Supra-national scale. Fertilizer Research 35, 227-235.

Turner, M.D., 1999. The role of social networks, indefinite boundaries and political bargaining in maintaining the ecological and economic resilience of the transhumance systems of Sudano-Sahelian West Africa. In: Niamir-Fuller, M. (Ed.), Managing Mobility in African Rangelands: The Legitimization of Transhumance. Intermediate Technology Publications, London, pp. 97-123.

Van den Bosch, H., Maobe, S., Ogaro, V.N., Gitari, J.N., Vlaming, J., 1998. Monitoring nutrient flows and economic performance in African farming systems NUTMON: III. Monitoring nutrient flows and balances in three districts in Kenya. Agriculture, Ecosystems and Environment 71, 65-82.

van Duivenbooden, N., 1996. La durabilité exprimée en termes d'éléments nutritifs - avec référence spéciale à l'Afrique de l'Ouest. Rapports PSS No. 29. Wageningen, The Netherlands. $268 \mathrm{pp}$.

Wezel, A., Boecker, R., 1999. Mulching with branches of an indigenous shrub (Guiera senegalensis) and yield of millet in semiarid Niger. Soil and Tillage Research 50, 341-344.

Wezel, A., Haigis, J., 2002. Fallow cultivation system and farmers' resource management in Niger, West Africa. Land Degradation and Development 13, 221-231.

Zada, A., 1999. Introduction des innovations agronomiques dans un contexte historique: sept études de cas au Niger. University of Hohenheim, Germany. 132 pp. 